\title{
Aggregata octopiana (Apicomplexa: Aggregatidae) from Octopus vulgaris off NW Spain
}

\author{
J. Estévez, S. Pascual, C. Gestal, M. Soto, H. Rodríguez, C. Arias* \\ Laboratorio de Parasitología, Facultad de Ciencias del Mar, Universidad de Vigo, Ap. 874, E-36200 Vigo, Spain
}

\begin{abstract}
Gamogony and sporogony of Aggregata octopiana were commonly observed during histological examination of the digestive tract and the connective tissue sheath of wild Octopus vulgaris (Cuvier, 1798) from Ria de Vigo (NW Spain). In massive infections, numerous oocysts were found in the muscular tissue.
\end{abstract}

KEY WORDS: Apicomplexa A Aggregata octopiana Octopus vulgaris

\section{INTRODUCTION}

Coastal octopus have the longest history of human exploitation of any cephalopod (Boyle 1990). The best known species, Octopus vulgaris Cuvier, 1798, is extremely important in fisheries (Roper et al. 1984). It also represents a major protein resource in most Mediterranean countries (Guerra 1992) and is widely used as a biomedical research model (Hanlon \& Forsythe 1985).

Despite their importance, little information is available on protozoan-related diseases occurring in wild populations, even in the common Octopus vulgaris. A notable exception is the coccidian Aggregata Frenzel, 1885 (Apicomplexa: Aggregatidae), which has been reported in the digestive tract of 13 octopus species worldwide (Sardella \& Re 1988, Hochberg 1990, Poynton et al. 1992).

This paper reports the first description of an apicomplexan of the genus Aggregata in Octopus vulgaris from eastern North Atlantic temperate waters.

\section{MATERIALS AND METHODS}

Between November 1994 and February 1995, 30 wild octopus were captured in artisanal gear by local fishermen from the Ria of Vigo (NW Spain). Tissues were excised from diverse regions of the digestive tract. Then, fresh material was examined by phase contrast

•Addressee for correspondence. E-mail: marias@setei.uvigo.es or fixed in $10 \%$ buffered formalin, embedded in paraffin and sectioned using a Microm HM-340 E microtome (Microm, Walldorf, Germany). Sections (4 to $5 \mu \mathrm{m}$ ) were stained with haematoxylin-eosin (Culling et al. 1985). Measurements of parasitic gamogonal and sporogonal stages was made using an ocular micrometer and are expressed in micrometers as ranges followed by the mean and standard deviations in parentheses $(n=30)$. The number of sporocysts was determined from each individual oocyst by using a Burker chamber. Terminology employed for parasitic stages follows Hochberg (1983).

\section{RESULTS}

Description of life cycle stages of Aggregata octopiana in Octopus vulgaris

Gamogony. The development of microgamonts was characterized by extensive cytoplasmic membrane folding, cytoplasmic partioning and an increase in the number of peripheral nuclei. Scores to thousands of flagellated microgametes were produced (Fig. 1).

Macrogamonts became macrogametes after a series of nuclear changes (Poynton et al. 1992). Macrogametes possessed foamy cytoplasm and a nucleus, containing a compact or ring-like nucleolus (Fig. 1D).

Both microgametes and macrogametes were surrounded by a pale homogenous area representing a parasitophorous vacuole. 


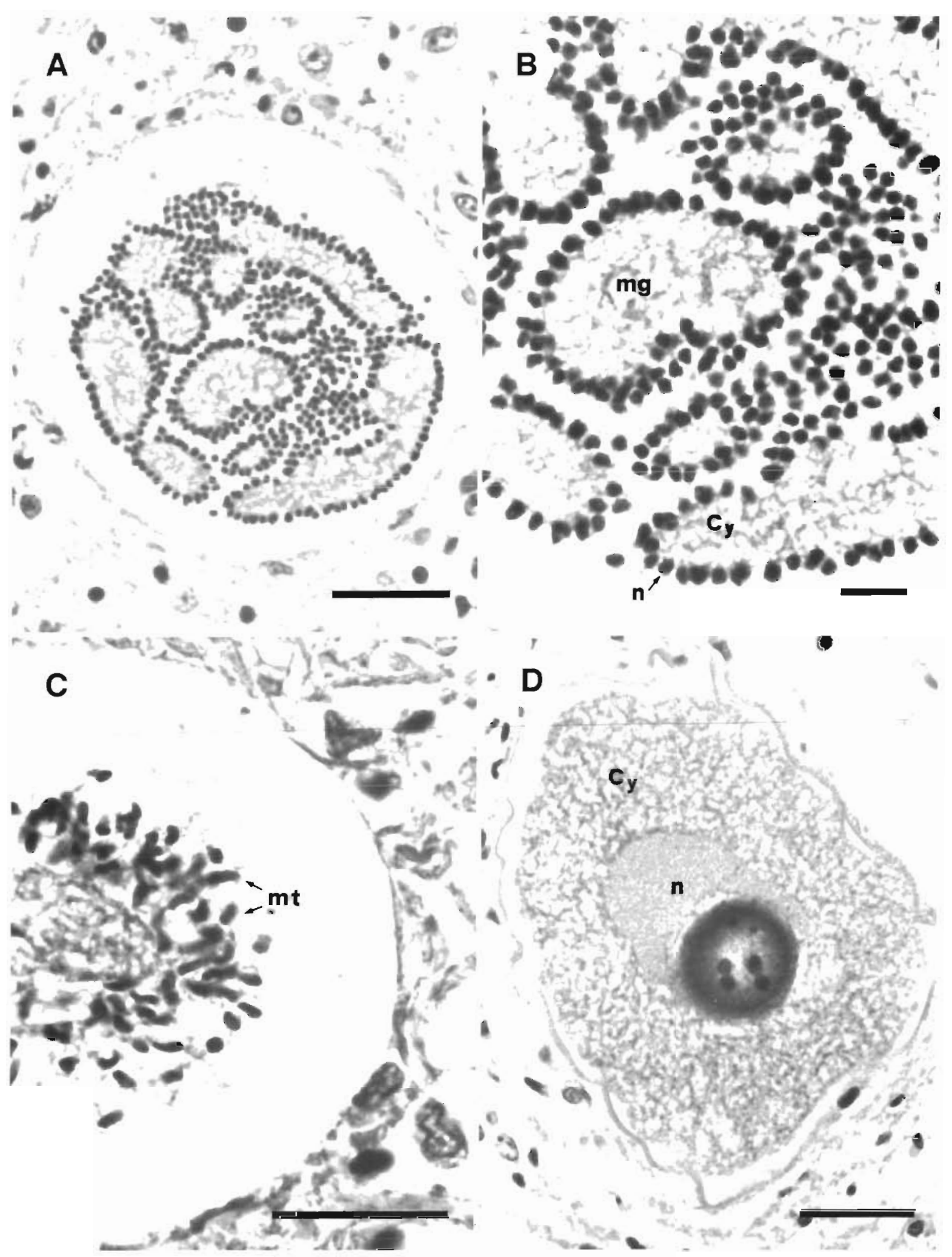

Fig. 1. Aggregata octopiana. Gamociony in Octopus vulgaris. (A to C) Successive stages in the formation of microgametes. (A) Microgamont characterind by extensive folding of the cytoplasmic membrane. Scale bar $=20 \mu m$. (B) Portion of microgamont (mg) showing the partitioned cytoplasm (C.y) and peripheral nuclei (n). Scale bar $=5 \mu \mathrm{m}$. (C) Microgametes (mt) completely formed. Scale bar $=20 \mu \mathrm{m}$. (D) Macrogamete with eccentric nucleus (n), conspicuous nucleolus and foamy cytoplasm. (Cy). Scale bar $=$ 


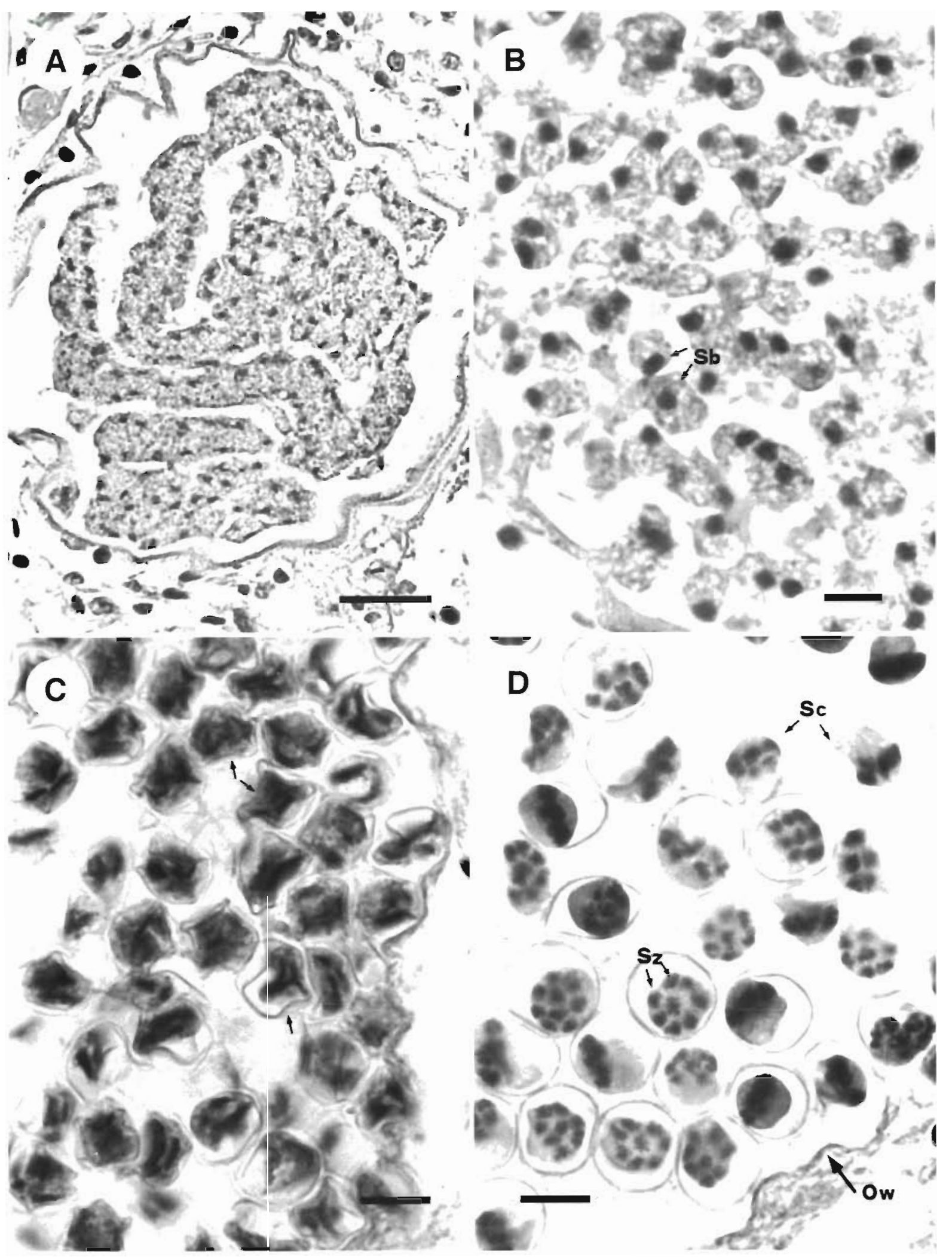

Fig. 2. Aggregata octopiana. Sporogony in Octopus vulgaris. (A) Sporont showing extensive folding of cytoplasmic membrane, and numerous nuclei at the periphery of the partitions. Scale bar $=25 \mu \mathrm{m}$. (B) Sporont segregating into uninucleate sporoblasts (Sb). Scale bar $=10 \mu \mathrm{m}$. (C) Immature sporocysts (arrows). Scale bar $=10 \mu \mathrm{m}$. (D) Oocyst containing mature sporocysts (Sc) with sporozoites (Sz). Ow: Oocyst wall. Scale bar $=10 \mu \mathrm{m}$. Stained with hematoxylin and eosin 

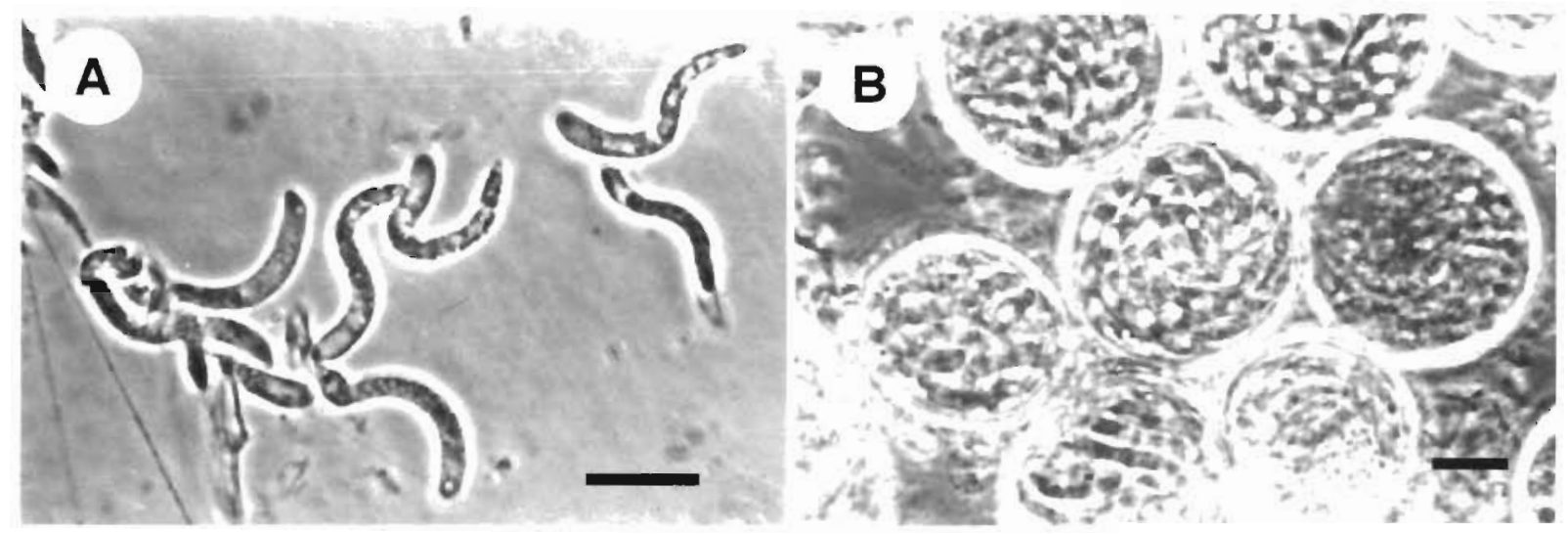

Fig. 3. Aggregata octopiana in Octopus vulgaris. Fresh microscopic examination of squash preparation, with phase contrast illumination. (A) Isolated sporozoites of A. octopiana. Scale bar $=10 \mu \mathrm{m}$. (B) Sporocysts of atypical size 'giants' containing from 20 to 26 sporozoites. Scale bar $=10 \mu \mathrm{m}$

Sporogony. The union of a microgamete and macrogamete produced a zygote, which then became an early sporont that was characterized by cell membrane folding and alignment of numerous nuclei on the surface of the partitioned cytoplasm (Fig. 2A). Individual nuclei with accompanying cytoplasm later budded off, forming uninucleate spherical sporoblasts (Fig. 2B). The development of sporoblast into sporocyst was characterized by an increase in the number of nuclei, and the further partitioning of nuclei and cytoplasm formed sporozoites (Fig. 2C, D). In fresh preparations, the sporocysts were spherical in shape, 11 to $15 \mu \mathrm{m}$ $(13.34 \pm 1.63)$ in diameter, and possess a smooth surface and a residual body. The sporocysts, which were composed of 2 equal halves joined together by a equatorial suture, opened at the suture, and released the sporozoites. The number of sporozoites for both fresh and sectioned material ranged from 6 to 12 per sporocyst. They were arranged in a spiral fashion inside the sporocyst with all nuclei at one pole. Isolated sporozoites were 16 to $23.5 \mu \mathrm{m}(19.77 \pm 2.46)$ long by 2 to $2.5 \mu \mathrm{m}(2.18 \pm 0.25)$ wide (Fig. $3 \mathrm{~A}$ ).

Oocysts were mainly oval but sometimes almost spherical in morphology and ranged in size from 200 to $1050 \mu \mathrm{m}(612.5 \pm 316.75)$ in length by 150 to $700 \mu \mathrm{m}$ $(402.5 \pm 155.99)$ in width. Multiple sporocysts were found within each oocyst, numbering between $<1000$ and 60000 . Approximately $10 \%$ of the oocysts examined possessed one or more atypically sized sporocysts ('giants') (Fig. 3B) with diameters of 23 to $32 \mu \mathrm{m}$ $(28.83 \pm 2.73)$ containing 20 to 26 sporozoites of sizes 27.5 to $31.5 \mu \mathrm{m}(29.83 \pm 1.44)$ long by 2.75 to $3.5 \mu \mathrm{m}$ $(2.97 \pm 0.23)$ wide.

\section{Prevalence and site of infection}

Routine histological examination of the digestive tracts of wild Octopus vulgaris from NW Spain demonstrated that gamogony and sporogony were present in all specimens examined (prevalence 100\%), most frequently in the digestive tract. The highest percentage of infection was found in spiral caecum, intestine, crop, digestive gland, oesophagus and connective tissue sheath. In one case of massive infection we also found oocysts of Aggregata octopiana in the muscle tissue.

\section{DISCUSSION}

Several authors (Sprague \& Couch 1971, Levine $1985,1988)$ have suggested that most species of Aggregata in Europe require redescription to determine their validity. Synonymy-related problems have

Table 1. Aggregata octopiana. Comparative data on morphology and dimensions of coccidia in Octopus vulgaris

\begin{tabular}{|ccccl}
\hline \multicolumn{2}{c}{ Sporocysts (Sc) } & \multicolumn{2}{c}{ Sporozoites } & \multirow{2}{*}{ Reference } \\
Surface & Diameter $(\mu m)$ & Number/Sc & Length $(\mu \mathrm{m})$ & \\
Smooth & $12-15$ & $9-16$ & $?$ & Moroff $(1908)$ \\
& 20 & 16 & $?$ & Wurmbach $(1935)$ \\
& $12-15$ & $8-16$ & $25-30$ & Hochberg (1990) \\
Smooth & $11-15$ & $6-12$ & $16-23.5$ & Present study \\
\hline
\end{tabular}


surfaced because Aggregata species have usually been differentiated on the basis of host, size and surface appearance of sporocysts, and number and length of sporozoites. With these diagnostic characters, Hochberg (1990) and Poynton et al. (1992) recognize 6 species of the genus Aggregata that are associated with cephalopod hosts: $A$. eberthi in Sepia officinalis (Dobell 1925), A. kudoi in S. elliptica (Narasimhamurti 1979), A. dobelli and A. millerorum in Octopus dofleini and $O$. bimaculoides respectively (Poynton et al. 1992), and $A$. octopiana and $A$. spinosa in O. vulgaris (Moroff 1908).

The characteristic morphological features of our species of Aggregata resemble those of the group formed by A. octopiana (Moroff 1908, Wurmbach 1935, Hochberg 1990) (Table 1), all having similar gamogonal and sporogonal stages. Both the diameter measurements of the sporocyst and the number of sporozoites were close to those described previously for this species. Sporozoite length, however (16 to $23.5 \mu \mathrm{m}$ ), was less than the length described by Hochberg (1990) (25 to $30 \mu \mathrm{m}$ ), but this may be explained by the presence of abnormally sized 'giant' sporocysts, found in $10 \%$ of the oocysts examined, measuring 27.5 to $31.5 \mu \mathrm{m}$ in diameter. The occasional presence of giant sporocysts had previously been observed by Dobell (1925) in A. eberhi, by Narasimhamurti (1979) in $A$. kudoi and by Poynton et al. (1992) in A. dobelli. Our finding of A. octopiana confirms the great extent of its geographical distribution and high specificity for the host.

Previously described Aggregata octopiana from octopus produced generalized infections in the digestive tract. The caecum appears to be the preferred site of infection. The unusual presence of the coccidians in the musculature, described here for the first time, is likely a result of the massive infections that occurred in the examined specimens. This unusual phenomenon has been described for other protozoan infections (Estévez et al. 1992).

Acknowledgements. We thank Dr F. G. Hochberg (Department of Invertebrate Zoology, Santa Barbara Museum of Natural History, USA) for his interesting comments on octopus parasites and helpful comments on early drafts of the paper This work was supported by the Spanish Government under Project CICYT-MAR 95-1919-C05-03.

Responsible Subject Editor: A. K. Sparks, Seattle, Washington, USA

\section{LITERATURE CITED}

Boyle PR (1990) Cophalopod biology in the fisheries context. Fish Res 8:303- 321

Culling CFA, Allison RT, Barr WT (1985) Cellular pathology technique. Butterworth \& Co, London

Dobell C (1925) The life-history and chromosome cycle of Aggregata eberthi (Protozoa: Sporozoa: Coccidia). Parasitology 17:1-136

Estévez J, Iglesias R, Leiro J, Ubeira FM, Sanmartín ML (1992) An unusual site of infection by a microsporean in the turbot Scophthalmus maximus. Dis Aquat Org 13: $139-142$

Guerra A (1992) Mollusca, Cephalopoda. In: Ramos MA (eds) Fauna Ibérica, Vol. 1 Museo Nacional de Ciencias Naturales CSIC, Madrid

Hanlon RJ, Forsythe JW (1985) Advances in the laboratory culture of Octopus for biomedical research. Lab Anim Sci 35(1):33-40

Hochberg FG (1983) Parasites of cephalopods: a review. Mem Natl Mus Victoria 44:109-145

Hochberg FG (1990) Diseases of Mollusca: Cephalopoda. Diseases caused by protistans and metazoans. In: Kinne O (ed) Diseases of marine animals, Vol. III. Biologische Anstalt Helgoland, Hamburg, p 47-202

Levine ND (1985) Phylum II. A.picomplexa Levine, 1970. In: Lee JJ, Hutner SH, Bovee EC (eds) An illustrated guide to the Protozoa. Society of Protozoologists, Lawrence, KS, p $322-374$

Levine ND (1988) The protozoan Phylum Apicomplexa, Vol I. CRC Press, Boca Raton, FL

Moroff T (1908) Die bei den Cephalopoden vorkommenden Aggregatarten als Grundlage einer kritischen Studie über die Physiologie des Zellkernes. Arch Protistenkd 11. $1-224$

Narasimhamurti CC (1979) The eimeriid Aggregata kudoi n. sp. from Sepia elliptica. Angew Parasitol 20:154-158

Poynton SL, Reimschuessel R, Stoskopf MK (1992) Aggregata dobelli $\mathrm{n}$. sp. and Aggregata millerorum n. sp. (Apicomplexa: Aggregatidae) from two species of Octopus (Mollusca: Octopidae) from the Eastern North Pacific Ocean. J Protozool 39(1):248-256

Roper CFE, Sweeney MJ, Nauen CE (1984) FAO species catalogue, Vol. 3. Cephalopods of the world. An annotated and illustrated catalogue of species of interest to fisheries. FAO Fisheries Synopsis 125

Sardella NH, Re ME (1988) Coccidian parasitosis by the genus Aggregata in Patagonian shallow water octopuses. 1. Aggregata sp. in Octopus tehuelchus d'Orbigny. Physis (B Aires) Secc A. 46(111):51-60

Sprague V. Couch J (1971) An annotated list of protozoan parasites, hyperparasites and commensals of decapod crustacea. J Protozool 18:526-537

Wurmbach H (1935) Über die Beeinflussung des Wirtsgewebes durch Aggregata octopiana und Klossia helicina. Arch Protistenkd 84:257-284

Manuscript first received: April 14, 1995

Revised version accepted: July 17, 1996 